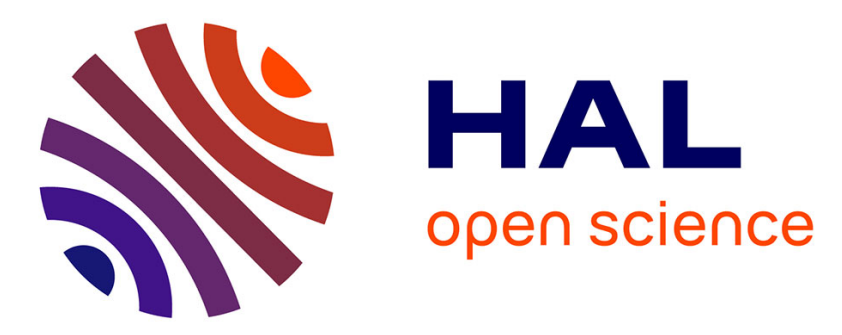

\title{
A novel, thermostable manganese-containing superoxide dismutase from
}

Ivanka Petrova Boyadzhieva, Miroslava Atanasova, Elka Emanuilova

\section{To cite this version:}

Ivanka Petrova Boyadzhieva, Miroslava Atanasova, Elka Emanuilova. A novel, thermostable manganese-containing superoxide dismutase from. Biotechnology Letters, 2010, 32 (12), pp.18931896. 10.1007/s10529-010-0368-8 . hal-00614503

\section{HAL Id: hal-00614503 https://hal.science/hal-00614503}

Submitted on 12 Aug 2011

HAL is a multi-disciplinary open access archive for the deposit and dissemination of scientific research documents, whether they are published or not. The documents may come from teaching and research institutions in France or abroad, or from public or private research centers.
L'archive ouverte pluridisciplinaire HAL, est destinée au dépôt et à la diffusion de documents scientifiques de niveau recherche, publiés ou non, émanant des établissements d'enseignement et de recherche français ou étrangers, des laboratoires publics ou privés. 


\title{
Section: Microbial and Enzyme Technology
}

A novel, thermostable manganese-containing superoxide dismutase from Bacillus licheniformis

\section{Ivanka Petrova Boyadzhieva", Miroslava Atanasova ${ }^{1}$, Elka Emanuilova}

Department of Extremophilic Bacteria, Institute of Microbiology, Bulgarian Academy of Sciences, 26, Acad. G. Bonchev str., 1113 Sofia, Bulgaria

"Corresponding author: E-mail: petrovaim@abv.bg; Tel: (359 2) 97931 10; Fax: (359 2) 8700109

${ }^{1}$ Present address: Department of Molecular Biology and Biotechnology, ANFACO - CECOPESCA Crta. Colegio Universitario 16, 36310 VIGO (Pontevedra), Espana

\begin{abstract}
A new, thermostable superoxide dismutase (SOD) from Bacillus licheniformis M20, isolated from Bulgarian mineral springs, was purified 11 -fold with $11 \%$ recovery of activity. From native PAGE and SDSPAGE, the enzyme was composed of two subunits of $21.5 \mathrm{kDa}$ each. The SOD was inhibited only by $\mathrm{NaN}_{3}$, which suggested that this SOD is of the manganese superoxide dismutase type. The purified enzyme had maximum activity at $\mathrm{pH} 8$ and $55^{\circ} \mathrm{C}$. The half-life of the SOD was 10 min at $95^{\circ} \mathrm{C}$.
\end{abstract}

Keywords: Bacillus licheniformis; Enzyme thermal stability; Manganese-containing superoxide dismutase; Purification 


\section{Introduction}

Superoxide dismutases (SODs, EC 1.15.1.1) are metalloenzymes, classified into three types: Mn-, Fe- and $\mathrm{Cu} / \mathrm{Zn}$-SOD according to their metal cofactors (Whittaker 2003). They are involved in the detoxification of the superoxide radicals $\left(\mathrm{O}_{2}^{-}\right)$to $\mathrm{H}_{2} \mathrm{O}_{2}$, which in turn is broken down to $\mathrm{H}_{2} \mathrm{O}$ by catalases and peroxidases. The superoxide radicals are generated by a single electron transfer to $\mathrm{O}_{2}$ and can damage DNA, proteins and lipids (Halliwell 2007).

An important requirement for SODs intended for industrial applications is their thermal stability as thermal denaturation is a common cause of enzyme inactivation. In this connection, an increasing interest to the SODs from thermophiles and hyperthermophiles were observed (Wang 2008). Thermostable SODs have also a higher resistance to most chemical denaturants and could be very useful in the industries of pharmaceuticals, cosmetics, food, and biotechnology and in environmental protection. SODs are crucial components in the physiological response to oxygen toxicity and are actively investigated as potential therapeutic agents in pathological conditions related to oxidative stress. Moreover, SODs offer a great potential for the sensitive quantification of $\mathrm{O}_{2}^{-}$in electrochemical biosensors (Campanella et al. 2001).

To our knowledge, studies describing SOD from Bacillus licheniformis are not available. Therefore, in the present work, the purification and biochemical properties of a novel, thermostable SOD from Bacillus licheniformis M20 are reported for the first time.

\section{Materials and methods}

Microorganism and growth conditions

Bacillus licheniformis M20 isolated from Bulgarian thermal springs (Dolna banja region), identified by 16S rRNA analysis and deposited in the EMBL GenBank DDBJ under accession number FN597717, was used. The strains was cultivated as described previously (Boyadzhieva and Emanuilova 2005).

SOD assay 
SOD activity was determined by the method of Beauchamp and Fridovich (1971). The reaction mixture in $3 \mathrm{ml}$ was composed of $20 \mathrm{mM}$ phosphate buffer (pH 7.8), $13 \mathrm{mM}$ L-methionine, $75 \mu \mathrm{M}$ NBT (Nitroblue Tetrazolium), $2 \mu \mathrm{M}$ riboflavin and $20 \mu \mathrm{l}$ purified enzyme. The test tubes were placed $30 \mathrm{~cm}$ below a fluorescent lamp (40 W). The reaction was initiated by turning the light on and reduction of NBT was determined by following the reading $\mathrm{A}_{560}$ for $5 \mathrm{~min}$. One unit of SOD activity was defined as the amount of the enzyme causing one half of the maximum inhibition of NBT reduction.

Protein concentration was estimated according to the Bradford method, using bovine serum albumin as standard.

All analyses of each sample were carried out in two repetitions and the data presented were obtained after three independent experiments, i.e. the data are mean values $\pm \mathrm{SD}, \mathrm{n}=6$.

\section{Results and discussion}

Purification of the SOD

A summary of the purification steps is given in Table 1. A purification of 11-fold with a yield of $11 \%$ was achieved. The SDS-PAGE and PAGE analysis of the purified enzyme revealed a single band (Fig. 1a). The molecular weight of the SOD was $22 \mathrm{kDa}$ by SDS-PAGE. The native PAGE and the zymogram showed a single active protein band with molecular weight $43 \mathrm{kDa}$ (Fig. 1b). These data indicated that the SOD from $B$. licheniformis M20 was dimeric. Most of the reported SODs are homodimers or homotetramers with subunits of about $20 \mathrm{kDa}$ (Whittaker 2003). The purified SOD was completely inhibited by $20 \mathrm{mM} \mathrm{NaN}$, but not by KCN and $\mathrm{H}_{2} \mathrm{O}_{2}$, suggesting that the enzyme belonged to Mn-SOD classification (Fig. 1c).

Properties of the SOD

The SOD from Bacillus licheniformis M20 was catalytically active only in the presence of $\mathrm{Mn}^{2+}$ (Table 2). The purified SOD was optimally active at pH 7.5-9, with maximum activity at pH 8 (Fig. 2a). The enzyme exhibited $60 \%$ relative activity at $\mathrm{pH} 9.5$, unlike other Mn-SODs, which rapidly lost its activity at pH over 7.8 (Seatovic et al. 2004). The optimum enzyme activity was established at 50-55 ${ }^{\circ} \mathrm{C}$ (Fig. 2b). The purified SOD from thermophilic Geobacillus kaustophilus ATCC8005 is optimal active at the same temperature, but with respect to the enzyme activity, SOD from $B$. licheniformis M20 exhibited $9780 \mathrm{U} \mathrm{mg}^{-1}$, compared to $1780 \mathrm{U} \mathrm{mg}^{-1}$ for 
Geobacillus kaustophilus SOD (Huang 2009). SOD from B. licheniformis M20 was distinguished with a high thermal stability, as shown in Figure 3. The half-life of the enzyme was 10 min at $95^{\circ} \mathrm{C}$. In comparison with the SOD from thermophilic Rhodothermus sp. XMH10, having half-life $30 \mathrm{~min}$ at $80^{\circ} \mathrm{C}$ (Wang et al. 2008) and the SOD from thermophile Thermomyces lanuginosus with half-life $30 \mathrm{~min}$ at $70-75^{\circ} \mathrm{C}$ ( $\mathrm{Li}$ et al. 2005), the SOD from B. licheniformis M20 had exceptionally better thermal stability.

The studied SOD from B. licheniformis M20, able to catalyze the conversion of superoxide ions or radicals under the moderate to high temperature environments is exceptionally useful in their removing or subtracting and has valuable potentials in different biotechnological processes. An advantage of the proposed SOD in the present work is its superior thermal stability, which could be provided a relatively longer functional action in the applied processes. The new, thermostable purified Mn-SOD from B. licheniformis M20 with its important features to be active at a high alkaline $\mathrm{pH}$ of the reaction media $(8 ; 9-9.5)$ and high temperatures $\left(75-95^{\circ} \mathrm{C}\right)$ could be a candidate for industrial uses.

\section{References}

Beauchamp C, Fridovich I (1971) Superoxide dismutase: improved assays and an assay applicable to acrylamide gels. Anal Biochem 44:276-278

Boyadzhieva I, Emanuilova E (2005) Characteristics of bacterial strain, superoxide dismutase producer, isolated from Bulgarian thermal spring. J Culture Coll 4:61-67

Campanella L, De Lusa S, Favero G, Tomassetti M (2001) Superoxide dismutase biosensors working in nonaqueous solvent. Fresenius J Anal Chem 369:594-600

Halliwell B (2007) Biochemistry of oxidative stress. Biochem Soc Trans 35:1147-1150

Huang SL (2009) Thermostable superoxide dismutase. United States Patent No US 2009/0311768 A1

Laemmli UK (1970) Cleavage of structural proteins during the assembly of the head of bacteriophage T4. Nature 227:680-685

Li DC, Gao J, Li YL, Lu J (2005) A thermostable manganese-containing superoxide dismutase from the thermophilic fungus Thermomyces lanuginosus. Extremophiles 9:1-6

Seatovic S, Gligic L, Radulovic Z, Jankov RM (2004) Purification and partial characterization of superoxide dismutase from the thermophilic bacteria Thermothrix sp. J Serb Chem Soc 69:9-16 
Wang X, Yang H, Ruan L, Liu X, Li F, Xu X (2008) Cloning and characterization of a thermostable superoxide dismutase from the thermophilic bacterium Rhodothermus sp. XMH10. J Ind Microbiol Biotechnol 35:133-139

Whittaker JW (2003) The irony of MnSOD. Biochem Soc Trans 31:1318-1321

Table 1 Purification process of SOD from B. licheniformis M20

\begin{tabular}{lccccc}
\hline Purification steps & $\begin{array}{c}\text { Total protein } \\
(\mathrm{mg})\end{array}$ & $\begin{array}{c}\text { Total activity } \\
(\mathrm{kU})\end{array}$ & $\begin{array}{c}\text { Specific activity } \\
\left(\mathrm{U} \mathrm{mg}^{-1}\right)\end{array}$ & $\begin{array}{c}\text { Enzyme yield } \\
\text { Purification }\end{array}$ & $($ fold $)$ \\
\hline Crude extract & 390 & 351 & 900 & 100 & 1 \\
$40 \%-60 \%\left(\mathrm{NH}_{4}\right)_{2} \mathrm{SO}_{4}$ & 100 & 200 & 2000 & $57 \pm 1.14$ & 2.2 \\
Phenyl- Sepharose & 40 & 168 & 4200 & $48 \pm 0.96$ & 4.7 \\
DEAE- Sepharose & 10 & 60 & 6000 & $17 \pm 0.34$ & 6.7 \\
Sephadex G - 100 & 5 & 41.75 & 8350 & $11.8 \pm 0.35$ & 9.2 \\
Sephadex G - 50 & 4 & 39.12 & 9780 & $11.1 \pm 0.28$ & 10.8 \\
\hline
\end{tabular}

After $5 \mathrm{~h}$ cultivation, the cells were collected by centrifugation ( $4500 \mathrm{x}$ g for $15 \mathrm{~min}$ ), and washed with 20 $\mathrm{mM}$ phosphate buffer ( $\mathrm{pH}$ 7.8). The pellets were suspended in the same buffer and the cells were ruptured by ultrasonic disintegration (three times in an ice bath for $2 \mathrm{~min}$ at $40 \mathrm{~V}$ ), and then the cell debris were removed by centrifugation $\left(10000 \mathrm{x}\right.$ g for $\left.15 \mathrm{~min}, 4^{\circ} \mathrm{C}\right)$. The resulting supernatant was precipitated with $40-60 \%$ saturated $\left(\mathrm{NH}_{4}\right)_{2} \mathrm{SO}_{4}$. After centrifugation $\left(10000 \mathrm{x} \mathrm{g}, 30 \mathrm{~min}, 4^{\circ} \mathrm{C}\right)$, the precipitate was dissolved in $20 \mathrm{mM}$ phosphate buffer and dialyzed against the same buffer overnight at $4^{\circ} \mathrm{C}$. The sample was loaded to a PhenylSepharose column $(2.5 \times 15 \mathrm{~cm})$, pre-equilibrated with $20 \mathrm{mM}$ Tris/HCl buffer $(\mathrm{pH} 7.8)$, containing $2.8 \mathrm{M}$ $\left(\mathrm{NH}_{4}\right)_{2} \mathrm{SO}_{4}$. The elution was carried out with the same buffer by stepwise decrease in the ionic strength of $\left(\mathrm{NH}_{4}\right)_{2} \mathrm{SO}_{4}$ ranging from 2.8 to $0.7 \mathrm{M}$. The fractions with SOD activity were pooled, dialyzed against $20 \mathrm{mM}$ phosphate buffer and loaded to a DEAE-Sepharose column $(2.5 \times 20 \mathrm{~cm})$, equilibrated with $20 \mathrm{mM}$ phosphate buffer. Elution of SOD was done with a linear gradient from 20 to $100 \mathrm{mM}$ phosphate buffer, $\mathrm{pH}$ 7.8. The active fractions were pooled and concentrated by ultrafiltration using PM-10 membrane (10 kDa; Amicon, Millipore, USA). The enzyme concentrate was applied to a Sephadex G-100 column, and then was loaded on Sephadex G-50 column. Gel filtration was carried out with $20 \mathrm{mM}$ phosphate buffer, $\mathrm{pH} 7.8$, on a self-packed column $(2.5 \times 25 \mathrm{~cm})$ 
Table 2 Specific activity of native, apo- and metal-reconstituted apo-SOD from B. licheniformis M20

\begin{tabular}{lc}
\hline Sample & Recovery activity (\%) \\
\hline Native SOD & 100 \\
Apo-SOD & 0 \\
Reconstitution with $10 \mathrm{mM} \mathrm{FeSO}_{4}$ & 0 \\
Reconstitution with $10 \mathrm{mM} \mathrm{MnSO}_{4}$ & 54 \\
Reconstitution with $10 \mathrm{mM} \mathrm{MnSO}_{4}+10 \mathrm{mM} \mathrm{FeSO}_{4}(1: 1, \mathrm{v} / \mathrm{v})$ & 52 \\
\hline
\end{tabular}

The initial activity of native SOD $9700 \mathrm{U} \mathrm{mg}^{-1} \pm 1.7 \%$ is taken as $100 \%$. The SOD was denatured by dialysis into $8 \mathrm{M}$ urea/10 mM EDTA/50 mM Tris (pH 8.0) for $12 \mathrm{~h}$ at $4^{\circ} \mathrm{C}$. The sample was then dialyzed into $50 \mathrm{mM}$ Tris $(\mathrm{pH} 8.0)$ for $12 \mathrm{~h}$ at $4^{\circ} \mathrm{C}$, which resulted in catalytically inactive SOD apo-protein. The sample of SOD apo- protein was divided into three dialysis bags and dialyzed for $4 \mathrm{~h}$ at $4^{\circ} \mathrm{C}$ against $8 \mathrm{M}$ urea-50 mM Tris buffer ( $\mathrm{pH} 8.0$ ), containing indicated above metal ions. After reconstitution, each sample was placed in $0.5 \mathrm{mM}$ EDTA-50 mM Tris $(\mathrm{pH} 8.0)$ for $12 \mathrm{~h}$ at $4^{\circ} \mathrm{C}$. The specific activity of each sample was measured by NBT reduction

Figure captions

Fig. 1 SDS-PAGE, PAGE and zymogram analysis of the purified SOD from Bacillus licheniformis M20. 
(a) Coomassie Briliant Blue staining. Lane 1: Protein marker, broad range (7-175 kDA, BioLabs, P7708S); Lane 2: SDS-PAGE; Lane 3: native PAGE. The electrophoreses were performed according to Laemmli (1970) on a $10 \%(\mathrm{w} / \mathrm{v})$ acrylamide gel. The protein was stained $15 \mathrm{~min}$ in a $0.2 \%$ Coomassie Brilliant Blue R250 (ethanol/acetic acid/distilled water). (b) Zymogram. Lane 1: Activity staining with NBT was done according to Beauchamp and Fridovich (1971). For the detection of SOD activity in gels, proteins were separated on a $10 \%$ non-denaturing PAGE. The gel was soaked in $730 \mu \mathrm{M}$ NBT solution for 15 min in the dark, followed by immersion with illumination in $38 \mathrm{mM}$ TEMED and $26 \mu \mathrm{M}$ riboflavin.

(c) The effect of inhibitors on the purified SOD. The samples were incubated for 60 min at $4{ }^{\circ} \mathrm{C}$ with the inhibitors and then used for a zymogram analysis. Lane 1: as the control, no treatment; Lane 2: $10 \mathrm{mM} \mathrm{KCN}$ as inhibitor; Lane 3: $40 \mathrm{mM} \mathrm{H}_{2} \mathrm{O}_{2}$ as inhibitor; Lane 4: $20 \mathrm{mM} \mathrm{NaN}_{3}$ as inhibitor

Fig. $2 \mathrm{pH}$ (a) and temperature profile (b) of the purified SOD from Bacillus licheniformis M20.

(a) SOD activity was measured under standard assay conditions at $\mathrm{pH}$ range of 512. The following buffers were used: $0.2 \mathrm{M} \mathrm{Na}$-acetate- $\mathrm{CH}_{3} \mathrm{COOH}(\mathrm{pH}$ 5-6), $0.2 \mathrm{M}$ potassium-sodium phosphate $(\mathrm{pH} 6.5-7.5)$ and $0.2 \mathrm{M}$ glycine- $\mathrm{NaOH}-\mathrm{NaCl}(\mathrm{pH} 8-12)$. The enzyme activity corresponding to $100 \%$ was $9670 \mathrm{U} \mathrm{mg}^{-1}$. Standard deviations of relative activities were in range of $0.5-1.4 \%$. (b) SOD activity was measured under standard assay conditions at temperatures over the range $30-90^{\circ} \mathrm{C}$ in $20 \mathrm{mM}$ phosphate buffer, $\mathrm{pH}$

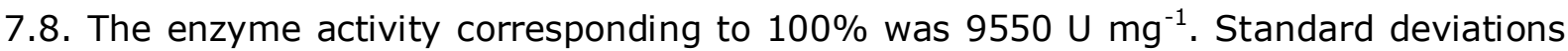
of relative activities were in range of $1.5-3.4 \%$

Fig. 3 Temperature stability of the purified SOD from Bacillus licheniformis M20. The enzyme was pre-incubated at various temperatures $\left(95^{\circ} \mathrm{C}\right.$-squares; $85^{\circ} \mathrm{C}$-triangles; $75^{\circ} \mathrm{C}$-circles; $65^{\circ} \mathrm{C}$-diamonds; $55^{\circ} \mathrm{C}$-empty circles) and at defined time intervals, the residual activities were determined under standard assay conditions. The non-heated 
enzyme was considered as $100 \%\left(9810 \mathrm{U} \mathrm{mg}^{-1}\right)$. Standard deviations of residual activities were in range of $0.7-2.7 \%$

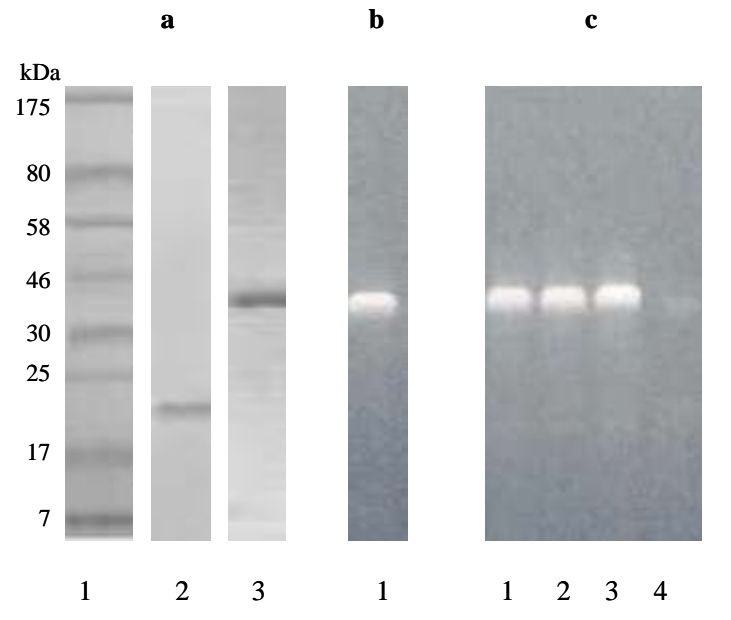

Fig. 1 

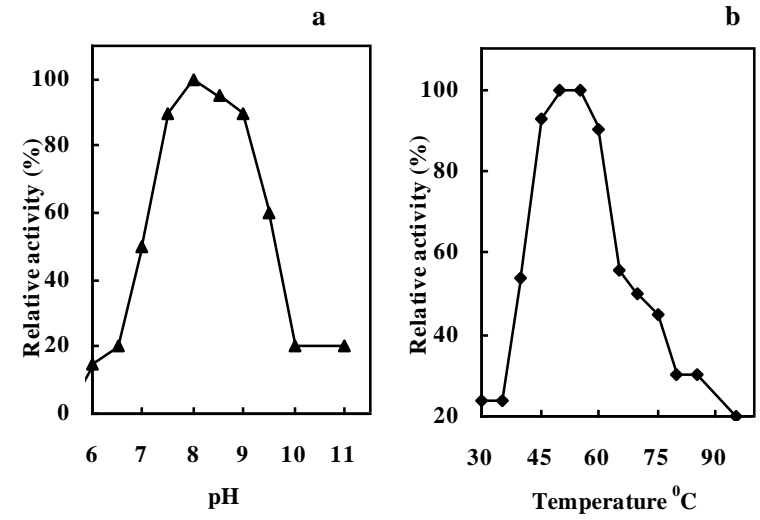

Fig. 2 


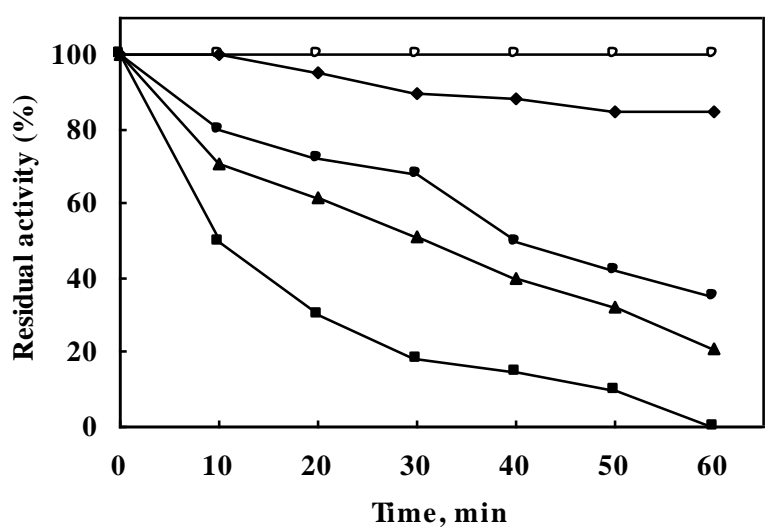

Fig. 3 